\title{
Library instruction the cooperative way
}

\author{
By Deborah J. Grimes
}

\section{A multi-institutional approach to teaching library skills}

$\mathbf{T}$ he days of the self-sufficient library are long gone. The information wildfire, which feeds off ever more rapidly changing information and telecommunications technologies, has changed the nature of the library forever. The information superhighway, which is not yet complete and not yet accessible at smaller libraries, holds great promise for college and university students. Many of these students, limited by their experiences, have no idea where the information superhighway can take them and what resources will be available. Academic library instruction programs must address this limitation and educate students to view the "library" in a different way. In an effort to promote information literacy ${ }^{1}$ in a broader context, Shelton State Community College, Tuscaloosa, Alabama, provides library instruction to over 800 students each semester within a multi-institutional environment by requiring students to utilize not only the Shelton State Library but also the local public library and the local university libraries. Institutional cooperation is vital to the success of the program.

\section{Factors for success}

How is a cooperative library instruction program developed? A key element of the success of the Shelton State library instruction program is cooperation among the staffs of Tuscaloosa Public Library (TPL), the University of Alabama (UA) Gorgas, or main, Library, the UA School of Library and Information Studies (SLIS), and Shelton State. A number of factors contribute to this success. First, there is frequent, twoway communication between librarians that fosters the climate in which multi-institutional instructional programs can flourish. Shelton State librarians were open and frank in their initial statements about the burdens the program would place upon the other libraries and their staffs. Shelton State librarians have regularly shared the results of surveys and other reports with the staffs of the other libraries, being careful to point out the positive responses of Shelton State students to the staffs of both the TPL and UA libraries. Problems reported by public and UA librarians are acted upon quickly.

A willingness to compromise has been evident in the communication between institutions. Shelton State librarians are willing to meet the requests of the other institutions in order to promote the LBS (library skills) sessions and activities in their facilities. Originally, UA bibliographic instruction librarians provided the UA sessions for Shelton State students. When this proved to be too much of a burden for the UA staff, the Shelton State librarians agreed to provide their own instructors. In addition, Shelton State librarians attempt to schedule sessions for their students when the UA students are not involved in BI activities.

Another contributing factor to the success of the programs is the location of the UA SLIS on the fifth floor of the UA Gorgas Library. In exchange for classroom space, Shelton State agreed to hire SLIS students to provide the UA sessions for its students. This agreement moved the Shelton State classes out of the UA bibliographic instruction classroom and provided SLIS students with both experience and employment. Shelton State library instructors hire, train, 
and monitor the SLIS instructors to ensure accurate and high-quality instructional sessions for their students. In addition, Shelton State library instructors are careful to set schedules, post directions, and provide instructions that remove burdens from SLIS administrative and office staff.

The only request made by the director of TPL in exchange for participation in the program was to have Shelton State students acquire library cards. Because the public library charges no fee for issuance of a library card, there is no additional cost to Shelton State students. This activity introduces or reintroduces the student to his/her local public library and encourages its use. It also helps to build the patron base of the public library, which is useful in obtaining funds from various sources.

Finally, Shelton State librarians have long maintained friendly, collegial relationships with public librarians, UA librarians, and SLIS faculty and administrators. Some of these relationships go back to shared library school classes, while some grew out of committee work and other professional projects. A reference librarian and former assistant director of TPL was one of the original library instructors in Shelton State's LBS programs. In addition, Shelton State librarians have fostered and maintained working relationships with administrators and supervisors at the public and UA libraries. Shelton State has been a willing site for SLIS student internships. All of these relationships provide a solid base upon which to build cooperative, interinstitutional library programs of all types.

\section{What is Shelton State's library instruction program?}

Shelton State Community College is a two-year institution which offers both vocational/technical training and academic educational programs to approximately 6,000 students in Tuscaloosa and the West Alabama community. Shelton State students enrolled in English Composition I and English Composition II classes are required to be concurrently enrolled in $\mathrm{Li}^{-}$ brary Skills (LBS 101) and Research Skills (LBS 102) courses, respectively. The library courses are one-hour, credit-bearing courses that include lecture, hands-on tool-specific exercises, and hands-on strategy-building exercises. Important components of the LBS courses are the requirements that students complete exercises at TPL and, after attencling orientation sessions, at the UA Gorgas Library.

\section{Learning about the university library}

Several objectives of LBS 101 and LBS 102 courses require Shelton State students to attend 50-minute orientation sessions and complete related exercises for each course at the UA Gorgas Library. Specifically, students in LBS 101, the basic introductory course, are expected to learn the location and layout of the UA Gorgas Library, and how to use Amelia, the UA online library catalog, for author, title, and subject searches. In addition, LBS 101 objectives include becoming familiar with UA library circulation policies and the location of UA branch libraries.

The objectives of the UA component of LBS 102 , the research skills course, are to learn more sophisticated search techniques, such as keyword searching, and to learn how to use specialized subject indexes or collections, such as Government Documents (available at UA Libraries but not at Shelton State Library). Because LBS 102 is designed to help students learn how to gather information and develop a research strategy for research papers, students seem to be particularly receptive to the UA component of the course. Emphasis is on helping the student locate resources that supplement those available at Shelton State.

Each semester, 40 to 45 classes, based on enrollment projections, are scheduled in both day and evening sessions in the UA Gorgas Library for Shelton State students. Students select a session and must have their exercise sheets stamped by the instructor as evidence of attendance. Students then must complete an exercise designed to help them locate resources and tools not available in the Shelton State Library. Generally, students stay a few minutes after the session to complete the exercise. This component both reinforces and facilitates the reciprocal borrowing agreement that has been in effect between the Shelton State and UA libraries since 1979 .

Because they are held in classrooms located on the fifth floor of the UA Gorgas Library, the sessions provide a friendly welcome to Shelton State students to a somewhat imposing research library. This approach addresses the threshold anxiety related to entering a new place by having someone waiting to meet Shelton State students and to provide instruction in using the UA libraries. Other agreements between Shelton State and UA, such as reciprocal recognition of faculty and stuclent parking decals, also contribute to the success of the program. 
Although there have been a number of complaints from Shelton State students about the requirement to attend UA sessions (and about the difficulties of parking on the UA campus in particular), survey results of small samples of students indicate that the components are quite effective. High numbers of students report that they feel better able to use the UA libraries after attending the session. Specific activities identified as helpful by students include: the tour of the UA Gorgas Library, learning about the UA reference room,

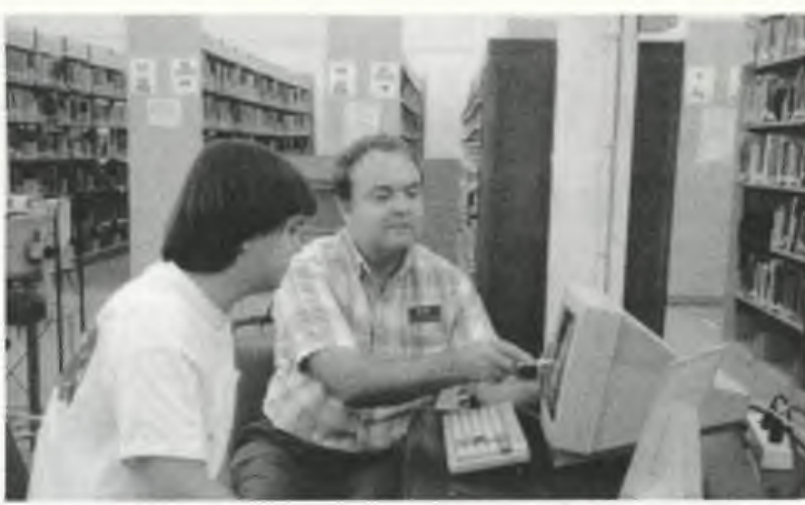

Shelton State librarian Don Bell teaches a student how to use the new automated system. learning about keyword searching, and learning about government documents. Informally, BI librarians at UA report that they find Shelton State students who have participated in the LBS program to be better prepared to use the UA libraries than are many other students.

\section{Learning about the public library}

The public library component of LBS 101 is designed to enable students to identify the system of classification in use at the public library, to identify and use the type of catalog available at the public library, to identify the location of current periodicals, and to identify a specific periodical reference (on a topic of student choice) by using TOM (a CD-ROM-based periodicals index available at the public library but not at Shelton State), and to acquire a public library card. There is no public library component of LBS 102.

At the beginning of the semester, LBS 101 students are given an exercise to be completed, outside of class, at TPL by a given deadline. The exercise is relatively simple, requiring the student to visit TPL and locate its major access tools. TPL staff members are provided with a stamp by Shelton State librarians and asked to stamp or sign each student's exercise, thus providing evidence that the student actually completed the exercise on site.

After initiation of the program in 1990 , small samples of students were informally surveyed to determine their level of satisfaction with the public library component of LBS 101. Results were surprisingly positive, falling in the 70 percent range for average or excellent ratings. When surveyed again in 1993 , results were even more positive. When asked to indicate what they felt to be the most beneficial aspects of the exercise, students indicated learning how to use TOM, acquiring a library card, and learning the location of the public library.

\section{Conclusions}

The multi-institutional components of Shelton State's LBS 101 and LBS 102 courses seem to be quite effective. The majority of students consistently earn high grades on UA and public library exercises, indicating successful completion of course objectives. Informal survey results show that students are meeting the objectives of the course highly satisfied with the instruction provided and the benefits gained.

Through LBS 101 and LBS 102 classes, Shelton State students are encouraged to view information literacy as an important aspect of college life and to interpret the concept of "library" in the larger sense of "libraries." Experiences gained at other libraries broaden their perspectives and help prepare them for the information superhighway. With indicators such as grades, student reactions, and librarians' reactions showing positive results, Shelton State will continue to promote institutional cooperation and, through it, information literacy within a multi-institutional environment.

\section{Note}

1. The definition of information literacy used in the Shelton State library instruction program is "the ability to locate, evaluate, and effectively use needed information," as outlined by Patrician Senn Brievik and Barbara J. Ford in "Promoting Learning in Libraries through Information Literacy," American Libraries 25 (January 1993): 98-101. 